\title{
A BLUE NEW DEAL
}

'A Blue New Deal is the first systematic look by a political theorist at the most important and most endangered global commons. Not only does Chris Armstrong provide a brilliant critical account of the origins of the failing oceanic governance, he also offers forward-looking guidance on how to design reforms towards justice and environmental sustainability. The range of issues addressed (from workers at sea and marine animals to small island states and seabed minerals) and a broad and practice-based approach to justice makes this book a must both for policy-makers and political theorists.'

Dr Petra Gümplová, University of Erfurt

'A Blue New Deal shows how our treatment of the sea aggravates both climate change and socioeconomic inequalities. It is rare for a book written by an academic to be so rich in facts and arguments and yet also fun to read. A mustread for academics, policy-makers and activists alike.'

Dr Dimitrios Efthymiou, Goethe University Frankfurt 


\section{A BLUE NEW DEAL \\ Why We Need a New Politics for the Ocean}

\section{GHRIS ARMSTRONG}

YALE UNIVERSITY PRESS

NEW HAVEN AND LONDON 


\section{Copyright (C) 2022 Chris Armstrong}

All rights reserved. This book may not be reproduced in whole or in part, in any form (beyond that copying permitted by Sections 107 and 108 of the U.S. Copyright Law and except by reviewers for the public press) without written permission from the publishers.

For information about this and other Yale University Press publications, please contact: U.S. Office: sales.press@yale.edu yalebooks.com

Europe Office: sales@yaleup.co.uk yalebooks.co.uk

Set in Adobe Garamond Pro by IDSUK (DataConnection) Ltd

Printed in Great Britain by TJ Books, Padstow, Cornwall

Library of Congress Control Number: 2021948941

e-ISBN 978-0-300-26499-9

A catalogue record for this book is available from the British Library.

109876654321 